\title{
Entre quarteirões, ribeiras e igarapés: resistência escrava, fronteiras e espacialidades afro-amazônicas (c.1850-c.1880).
}

\author{
Between city blocks, riverside forest and creeks: slave resistance, \\ borders and african-Amazonian spatiality (c.1850-c.1880)
}

Ygor Olinto Rocha Cavalcante ${ }^{1}$

\begin{abstract}
Resumo
Neste artigo analisa-se as relações entre a construção de espaços e territórios com base nas experiências de fugitivos escravos, mocambeiros e comunidades quilombolas no processo de resistência à escravidão no Amazonas. Os diversos enfrentamentos no cotidiano da escravidão, envolvendo diferentes sujeitos sociais, está atrelado à definição de fronteiras sociais e espaciais na região. Argumenta-se, assim, que os fugitivos forjaram, nos seus próprios termos, outros limites para as fronteiras nacionais e para os espaços urbanos, na contramão das delimitações impostas pelas políticas de elites e de governos dos Estados Nacionais. Por fim, objetiva, ainda, contribuir para retirar o véu de invisibilidade social que ainda hoje atinge as comunidades remanescentes de quilombo no Amazonas.
\end{abstract}

Palavras-chave: Resistência Escrava; Territórios; Amazonas.

\begin{abstract}
This article analyzes the relationships between building spaces and territories based on the experiences of runaway slaves, maroons and quilombolas communities in resistance to slavery in the Amazon process. The various confrontations in everyday slavery, involving different social subjects, is related to the definition of social and spatial boundaries in the region. It is argued, therefore, that the fugitives have forged in its own terms, other limits to national boundaries and urban spaces, against the boundaries imposed by political elites and governments of nation states. Finally, objective also help lift the veil of social invisibility that today still affects the remaining Quilombo communities in the Amazon.
\end{abstract}

Keywords: Slave Resistance; Territories; Amazon.

Artigo recebido em: 16/01/2014

Artigo aprovado para publicação em: 16/02/2014

O presente artigo avalia as relações entre fugas escravas e a construção de territorialidades durante a segunda metade do oitocentos no Amazonas. Parte-se da

\footnotetext{
${ }^{1}$ Graduado em História pela Universidade Federal do Amazonas, mestre em História pela mesma universidade e professor do Instituto Federal de Educação do Amazonas - campus Coari. Email: ygor.olinto@gmail.com
}

Revista Eletrônica da ANPHLAC, ISSN 1679-1061, n. 16, p. 26 - 56, Jan./Jul. 2014. http://revista.anphlac.org.br 
compreensão de que os espaços sociais são lócus de luta, de conflitos e de solidariedades entre os sujeitos históricos e, por conseguinte, argumenta-se a estreita relação entre dinâmica social e a construção de espacialidades, refletindo processos de enfrentamentos culturais e políticos. No caso das populações negras - organizadas em mocambos, construindo laços de solidariedade para viver fugidos do cativeiro, arranjos familiares em liberdade ou mesmo entre aqueles que buscavam transformar as relações escravistas à base de enfrentamentos mais severos no ambiente urbano - verifica-se a complexa (e diversificada) constituição de territórios atravessados pela resistência à escravidão na região amazônica. Nesse sentido, este texto pretende contribuir para o adensamento das discussões à respeito das trajetórias históricas das populações negras e quilombolas da região, garantindo maior suporte ao debate sobre as situações de conflito que ainda hoje atingem as comunidades quilombolas e povos tradicionais da Amazônia. ${ }^{2}$

\section{Fugas e fugitivos no Amazonas, séc. XIX.}

No Amazonas, os homens e mulheres que através das fugas buscavam redefinir as relações com seus senhores, ou mesmo romper com o cativeiro, seguiram por diversas direções entre rios, lagos, igarapés e quarteirões. Individual ou coletivamente, por motivações semelhantes ou completamente díspares, os escravizados chegaram aos lugares mais longínquos da província, circulando em zonas de fronteira internacional, homiziados nas cabeceiras dos rios, ou a atingir lugares pouco ocupados, construindo suas próprias territorialidades.

A maioria dos fugitivos migraram de regiões do próprio Amazonas. Resultado previsível tendo em vista que trabalhamos especificamente com anúncios da imprensa

\footnotetext{
${ }^{2}$ No Amazonas, as comunidades negras e quilombolas sofrem com uma profunda invisibilidade social. $\mathrm{O}$ famigerado argumento da inexpressividade da escravidão e da diminuta presença de africanos nos tempos de colonização na região vêm reforçar as tentativas, do que bem avaliou Alfredo Wagner Berno de Almeida (ALMEIDA, 2010, p.12), de "desautorização etnográfica e de ilegitimação" dos critérios de competência científica de antropólogos, historiadores e demais profissionais envolvidos no processo de avaliação para o reconhecimento das comunidades remanescentes de quilombos (e da política identitária que ocorre em paralelo), concernentes à "campanha de desterritorialização perpetrada pelas agroestratégias das entidades patronais e conglomerados industriais, pelas ações jurídicas de partidos políticos da chamada 'bancada ruralista', pelas formulações de think tanks conservadores ou grupos experts da indústria cultural e editorialistas de grandes periódicos e pelos atos de agencias governamentais ditas de 'segurança institucional' ou responsáveis pela implantação de 'grandes projetos"”.
}

Revista Eletrônica da ANPHLAC, ISSN 1679-1061, n. 16, p. 26 - 56, Jan./Jul. 2014. http://revista.anphlac.org.br 
amazonense. Contudo, ocorre que algumas dessas fugas originaram-se na província do Pará e uma no Maranhão. Vale ressaltar o quadro amplo de localidades, apontadas pelos senhores nos anúncios, em que se originaram as fugas. Estes sujeitos enfrentavam enormes distâncias e seguiam rotas severas pelo vale amazônico.

A qualidade desse deslocamento sugere a existência de rotas sólidas e a mobilização de uma bem construída rede de relações sociais. Afinal, sair de um lado do império para os seus confins requer, no mínimo, certa "bagagem" de experiências para vencer distâncias tão hostis. Quando Gabriel fugiu da província do Maranhão, em dezembro de 1873, tinha mais ou menos 20 anos de idade e sabia ler e escrever. Trabalhava alugado em uma tipografia do jornal Paiz. De acordo com o senhor, o fujão possuía pelo menos três destinos prováveis: Amazonas, Pará, e ainda, a "não ser boato de propósito espalhado", a cidade de Lisboa. Ora, o propósito do "boato" talvez fosse o de despistar o senhor de Gabriel, isto é, estratégia no sentido de confundir as tentativas de captura-lo (Comércio do Amazonas, 11/01/1874).

Das informações recolhidas nos anúncios, pode-se perceber certo equilíbrio no número de fugas entre as localidades de Barcarena, Cachoeira do Marajó e Belém, e sugere a predominância de Óbidos entre os fugidos do Pará. Esta região do baixo Amazonas, nas áreas ao longo do rio Tocantins e seus afluentes, foi um lugar com forte presença de africanos trabalhando nos engenhos; regiões em que se constituíram diversos mocambos e comunidades de fugitivos, desde o período colonial. No Amazonas, encontram-se pelo menos cinco polos de origens de fuga (Silves, Serpa, regiões de extração de seringa no rio Madeira, rio Negro e Manaus). No Pará, as evasões ocorreram de cinco lugares diferentes.

Em 24 de novembro de 1862, o capitão Felipe Joaquim Batalha anunciou a fuga do escravo Hilário. Ambos seguiam a bordo da coberta "Nossa Senhora da Conceição", com destino ao Pará, quando o escravo escapou em São José do Amatary - um povoado às margens do rio Amazonas, bem próximo à embocadura do rio Madeira. Pelas referências de Paul Marcoy, o pequeno povoado era formado "por umas casas espalhadas numa faixa de terra nua na margem esquerda do Amazonas" e, via navegação, estava há pelo menos quarenta e cinco minutos da Vila de Serpa (MARCOY, 2006, pp. 193-203).

Revista Eletrônica da ANPHLAC, ISSN 1679-1061, n. 16, p. 26 - 56, Jan./Jul. 2014. http://revista.anphlac.org.br 
Hilário, filho do rio Bujaru, segundo dizia seu senhor, era um "crioulo retinto, de trinta anos de idade, baixo, magro, barba serrada, dentadura perfeita, pés pequenos". O fujão era "bem falante e desembaraçado", apesar dos graves problemas que possuía na coluna que inclinavam seu corpo, resultado de uma "fratura que recebeu na espinha dorsal”. O capitão Joaquim Batalha era viajado e experiente autoridade policial nos rios do Amazonas. Havia atuado como capitão de polícia nas áreas de fronteira internacional entre Brasil e Peru, conhecia os postos de Tabatinga com estadas em Loreto. E não foi à toa que se preocupou em registrar a naturalidade de Hilário "como filho do Bujaru", uma importante área escravista, com alta densidade de população escrava e concentração de mocambos (Estrella do Amazonas, 26/11/1862). Hilário conhecia a região e seus habitantes. Ali certamente encontraria abrigo e proteção. ${ }^{3}$ No dia de sua fuga, Felisberto vestiu-se com a mesma elegância de costume. Em 17 de maio de 1875, o senhor José Gusmão da Silva Amaral anotou as seguintes características do cativo: "mulato, estatura regular, muito falador". Fugiu do rio Madeira, a bordo do Vapor Amazonas. Durante seis semanas seguidas José Gusmão publicou o anúncio, sem ter sucesso. Os destinos prováveis eram muitos, pois além de Manaus e o Rio Madeira, o cativo poderia ter escapado para a proteção de um dos antigos senhores (Commércio do Amazonas, 24/06/1875).

Muitos senhores suspeitavam que seus cativos buscassem refúgio em Manaus. Outros tantos acreditavam que a província do Pará, especialmente a cidade de Belém, era o lugar preferido para o esconderijo. Embora os dados sejam relativos apenas ao Amazonas nota-se que Manaus é o principal local de origem e de destino dos fugitivos. Esta é uma característica relevante para a compreensão dos limites do cativeiro e da dominação senhorial, mas sobretudo para o melhor entendimento do processo de construção da cidade de Manaus e de sua vida urbana na segunda metade do século XIX. O Amazonas possuía altos índices de população escrava em idade produtiva $(62,9 \%)$ e uma das mais altas porcentagens de cativos vivendo em ambiente urbano em todo o Império $(50, \%)$. O perfil da escravidão local, desse modo, era eminentemente urbano (MARCONDES, 2005, p.87).

\footnotetext{
${ }^{3}$ Sobre Felipe Joaquim Batalha verificar (BASTOS, 2008, p.15). As informações sobre Bujaru ver (BEZERRA NETO, 2002, pp.222-228).
}

Revista Eletrônica da ANPHLAC, ISSN 1679-1061, n. 16, p. 26 - 56, Jan./Jul. 2014. http://revista.anphlac.org.br 
Mais da metade da escravaria da província circulava por Manaus, estava apta ao trabalho e, de alguma forma, esteve em contato com algum fugitivo. Embora as formas de produção e reprodução da vida material da província não dependessem integralmente do trabalho escravo, as poucas ruas da cidade e seus subúrbios contavam com as atividades dos negros e com os vários serviços desempenhados pela população escravizada. Eram os negros "aguadeiros" que coletavam água juntamente com os índios nos igarapés ou nas fontes para venderem aos cidadãos, os "negros de ganho" alugando seus préstimos, quer fosse para carregar pedras, colunas ou mercadorias, quer fosse para os serviços domésticos; havia ainda os negros carroceiros que transportavam os habitantes para diferentes lugares na cidade; as escravas de "bons costumes", vendedeiras, quitandeiras, engomadeiras, costureiras; os sapateiros, ferreiros, carpinteiros, e outros mais serviçais domésticos.

\section{Manaus-esconderijo}

Antiga Vila da Barra, criada como cidade em 24 de outubro de 1848, passou a se chamar Manaus oito anos depois de sua fundação. Existem alguns relatos de viajantes para a década de 1830 que descrevem a Comarca do Alto Amazonas como um lugar parcamente povoado, com pequenas e modestas vilas habitadas predominantemente por indígenas destribalizados. Contudo, a história de Manaus enquanto cidade-esconderijo de fugitivos é pouco frequentada pela historiografia.

No contexto de crise e retração econômica no qual ocorre a criação da Província do Amazonas, a cidade da Barra nada mais é do que um pequeno lugar no meio da floresta. O decurso da segunda metade do século XIX assiste à uma ligeira modificação desse quadro. A cidade passa por transformações de seu espaço urbano que se iniciam na década de 1840, resultado da maior injeção de investimentos no setor imobiliário. As intervenções na pequena vila acompanham o ritmo da expansão da economia da borracha. $\mathrm{O}$ avançar das modificações urbanas, caudatárias da economia gomífera, traz consigo o confronto de modelos diferenciados de sociedade e de projetos de cidade. De um lado, a diminuta população branca passa a adotar os comportamentos europeus para reiterar seus valores de elite; de outro, os hábitos e costumes tradicionais da grande maioria dos habitantes, notadamente de raízes indígenas, impõem limites aos projetos

Revista Eletrônica da ANPHLAC, ISSN 1679-1061, n. 16, p. 26 - 56, Jan./Jul. 2014. http://revista.anphlac.org.br 
civilizatórios. A elaboração e reelaboração espacial da cidade, isto é, as práticas que construíram efetivamente a cidade estavam em permanente conflito. E a capital da província surge exatamente nesse campo de disputas sociais e culturais.

As tentativas de mudanças na malha urbana foram inúmeras. Os jornais veiculavam com frequência seus próprios projetos de cidade, enumeravam as ações do Estado provincial e apresentavam negativamente os costumes das camadas subalternas. Surgiam novos prédios, novas praças e ruas. Os igarapés que circundavam a cidade sofreram pequenas intervenções no sentido de instalar as bases do projeto de capital idealizado pelas elites locais. Tratando do assunto, $O$ Catechista argumentava:

A cidade de Manaus pela sua posição topográfica e como capital de uma província cujo futuro grandioso, sendo desde já pressentido, não precisa ser preconizado, há de, necessariamente, ser a mais bela, rica e importante das cidades que se prenderam no extenso Vale do Amazonas e de seus confluentes, quando o crescimento das gerações do provir tiver dado ao seu comércio e industrias o incremento de que eles são suscetíveis, e cujos elementos a natureza aí semeou com prodigalidade, para que a mão do homem as aproveitasse $(O$ Catechista, 01/04/1865).

Para a imprensa local a questão do desenvolvimento urbano precisava de maior atenção dos governantes locais. O discurso corrente entre os redatores consistia no seguinte argumento: criar um ambiente propício para o bem estar da população que passava por um período de incremento significativo. Crescimento urbano, nessa conjuntura, passa a ser sinônimo de novos postos de trabalho, alta demanda por trabalhadores especializados, novas ruas e vielas. Esses projetos reforçavam a ideia de bem estar da população aliada ao progresso material; como resultado desses processos, criavam-se espaços sociais diferenciados - os construídos pelas elites e os recriados pelos menos afortunados.

Nesse contexto, Manaus passa a receber uma quantidade difícil de ser mensurada de pequenas embarcações vindas das vilas do interior da província; de navios vindos do Pará, do Mato Grosso; de vapores dos países das fronteiras da América e, também, da Europa. A abertura definitiva do rio Amazonas no final da década de 1860 a todos os "países amigos" atraiu investimentos estrangeiros e ajudou a incrementar as atividades mercantis na região. Ademais, permitiu a incorporação definitiva da região amazônica ao conjunto do Império, vez que o trânsito regular de

Revista Eletrônica da ANPHLAC, ISSN 1679-1061, n. 16, p. 26 - 56, Jan./Jul. 2014. http://revista.anphlac.org.br 
navios foi a solução mais vantajosa de desenvolvimento econômico encontrada pelas elites políticas (GREGÓRIO, 2009, p.185-212). A própria demanda internacional da borracha intensificou este processo, diziam os jornais (O Catechista, 23/01/1864).

Portanto, as décadas de 1850 e 1860 assistem a um processo de aumento populacional. A partir de 1870, ainda mais trabalhadores, sobretudo nordestinos, serão atraídos para a região seduzidos pela economia da borracha. O fluxo crescente de pessoas não apenas trazia migrantes de países europeus (entre portugueses, franceses e italianos), mas principalmente os "nacionais", entre livres e escravos. O relatório presidencial do Tenente Coronel João Wilkens de Mattos informa aos deputados que:

Das comarcas de Gurupá e Santarém da província do Pará, tem entrado para os rios Madeira e Purus alguns milhares de pessoas, que neles se dedicam à indústria extrativa. Ultimamente entrou uma colônia cearense, e espera-se que até o mês de Julho do corrente ano, o tenente-coronel Lebre, que visitou o alto Purus, venha da província do Maranhão acompanhado de algumas dezenas de pessoas, livres e escravas, com o intuito de estabelecer-se naquele rio (AMAZONAS, 1870, p.27)

É certo que esse trânsito de pessoas, embarcações e mercadorias criou uma esfera de "desobediência" e frequentemente confundia as fronteiras sociais entre os menos afortunados da pequena cidade. À medida que os investimentos no setor imobiliário se faziam sentir, a circulação de trabalhadores também aumentava. $O$ universo social da província estava cada vez mais complexo. E isso, de alguma maneira, facilitava a invisibilidade dos fugitivos. Em março de 1872, o presidente da província Dr. José de Miranda da Silva Reis, sinalizava "o progressivo aumento da população da província e as sérias dificuldades com que se luta para de pronto se fazer chegar aos diversos pontos desta a ação da justiça" (AMAZONAS, 1872, p.6). Assim, o aumento do contingente populacional, formado, sobretudo, por nacionais, entre livres e escravos, significava maior tensão social e evidenciava os limites das políticas de controle social.

Com efeito, em paralelo às modificações urbanas, por conseguinte, existiu um processo de complexificação social. Escravizados, libertos, africanos, crioulos, fugitivos, indígenas de diversas etnias, bolivianos, peruanos, cearenses, maranhenses, franceses, portugueses, compartilhavam espaços sociais no ambiente de trabalho, nas tabernas, praças, nos portos da cidade, produziam culturas urbanas e novos territórios, misturavam-se - tanto nos conflitos quanto nas redes de solidariedade.

Revista Eletrônica da ANPHLAC, ISSN 1679-1061, n. 16, p. 26 - 56, Jan./Jul. 2014. http://revista.anphlac.org.br 
As listas de matricula e o Censo de 1872 permitem observar esses contatos culturais e sociais. Utilizando as informações sobre o gradiente de cores associadas à condição escrava pode-se perceber que as fronteiras entre livres, libertos e escravos eram bem pouco nítidas (do ponto de vista das classificações por cor/raça, tal como se fazia na época), configurando, assim, paisagens sociais de invisibilidade para os fujões.

Conforme a classificação do Censo Geral do Império de 1872, existiam apenas duas "cores" possíveis para identificar escravos. Cerca de $30 \%$ dos indivíduos de cor preta da cidade estavam escravizados e, na mesma categoria, pouco mais de $10 \%$ dos pardos. Portanto, isto significa que apenas $13 \%$ dos habitantes de Manaus, que possuíam fenótipo associado à escravidão, eram, efetivamente, escravos. Ou seja, 87\% de indivíduos de cor preta e parda, segundo o recenseamento, eram homens livres. Infelizmente não podemos indicar quantos deles nasceram em liberdade ou foram libertados por alforria. Seja como for, os dados do Censo revelam um ambiente propício para a invisibilidade dos fugitivos em meio à população negra livre.

Entretanto, se apenas os dados do Censo forem cotejados para a análise deste complexo universo social corre-se o risco grave de perder de vista algumas características específicas da escravidão no Amazonas. Isto porque os dados coletados pelo Estado Imperial ignoram a existência no Brasil de pessoas escravizadas identificadas costumeiramente a partir dos fenótipos "branco" e "caboclo". Sem maiores explicações, os organizadores do recenseamento do império decidiram que não havia escravos de cor branca ou mesmo caboclos no Brasil. Talvez já informados pelas teorias raciais da época (ALENCASTRO, 1997, p.87-88). É preciso considerar ainda a existência de certo preconceito racial que identificava no negro a escravidão, corrente no imaginário da época, que pesou sobre as respostas dos informantes do recenseamento (OLIVEIRA, 2003, p.10). Uma forma de solucionar esta limitação é confrontar os dados do Censo aos da Listas de Matrícula (1869) e Classificação (1873). Vejamos as tabelas abaixo:

Tabela I - Cor e Condição Escrava.

\begin{tabular}{||l|c|c||}
\hline \multicolumn{1}{|c|}{ Cores } & Qtd. & $(\%)$ \\
\hline \hline Preta & 145 & 41,07 \\
\hline Parda & 73 & 20,67 \\
\hline Carafuza & 72 & 20,11 \\
\hline
\end{tabular}

Revista Eletrônica da ANPHLAC, ISSN 1679-1061, n. 16, p. 26 - 56, Jan./Jul. 2014. http://revista.anphlac.org.br 


\begin{tabular}{|l|c||c|}
\hline Cabocla & 8 & 2,26 \\
\hline \hline Mulata & 54 & 15,01 \\
\hline Branca & 3 & 0,84 \\
\hline
\end{tabular}

Fonte: Lista de Matrícula dos Escravos da Comarca da Capital, 1869.

Tabela II - Cor e Condição Escrava

\begin{tabular}{|l|c||c||}
\hline \multicolumn{1}{|r|}{ Cor } & Qtd. & (\%) \\
\hline \hline Preta & 336 & 45,71 \\
\hline Mulata & 159 & 21,63 \\
\hline \hline Carafuza & $\mathbf{1 3 6}$ & $\mathbf{1 8 , 5 0}$ \\
\hline Parda & 71 & 9,65 \\
\hline \hline Tapuia & 12 & 1,63 \\
\hline \hline Cabocla & 6 & 0,81 \\
\hline \hline Cabra & 4 & 0,54 \\
\hline \hline Fula & 4 & 0,54 \\
\hline \hline Crioula & 2 & 0,27 \\
\hline \hline Caboré & 1 & 0,13 \\
\hline $\begin{array}{l}\text { Sem } \\
\text { Informação }\end{array}$ & 4 & 0,54 \\
\hline \hline
\end{tabular}

Fonte: Lista de Classificação dos Escravos para Emancipação, 1873.

De acordo com as informações acima, as "cores" que podiam identificar um individuo como escravo, nos cenários urbanos, no ambiente de trabalho ou nas horas de descanso e lazer, eram muitas. Nesse sentido, distinguir a população livre da escrava em termos raciais era tarefa muito difícil. Pesquisas para o Brasil Colonial argumentam que existia uma infinidade de termos raciais, o que impossibilitava a criação de critérios objetivos, em bases raciais, para diferenciar a população (RUSSEL-WOOD, 2005). Os termos incluíam as denominações correntes branco, preto e pardo, mas também recorria-se à expressões pouco definidas como mestiços, cabra, crioulo, trigueiro, moreno, escuro. Não sendo satisfatório o uso de tais termos para atestar o grau de brancura ou negritude de uma pessoa, usava-se a permutação de vários termos. Conforme argumenta Russel Wood:

A endogamia com base em cor não existia na América Portuguesa e a impossibilidade de estabelecer um conjunto de critério objetivos para designar a identidade racial de uma pessoa é não só herança do período colonial nos dias de hoje como uma característica que

Revista Eletrônica da ANPHLAC, ISSN 1679-1061, n. 16, p. 26 - 56, Jan./Jul. 2014. http://revista.anphlac.org.br 
distingue o Brasil das colônias inglesas e, mais tarde, dos Estados Unidos (RUSSEL-WOOD, 2005, p.49) ${ }^{4}$

Nos anúncios de fuga também aparecem de forma frequente certas expressões: mulato claro, preto não retinto, fula, moreno, mulato atapoiado, cafuzo atapoiado, pardo escuro, crioulo retinto, mulato alvacento, entre outros. É bem verdade que muitas dessas denominações só possuíam valor de referência para aquele que emitia a classificação. $\mathrm{Na}$ maioria das vezes, pelo caráter inteiramente subjetivo das expressões, os mesmos indivíduos eram classificados de maneiras distintas pelos avaliadores. O fugitivo Tristão, por exemplo, em março de 1869, quando seu senhor ainda estava vivo, o comerciante Hermenegildo Lopes Braga, foi classificado no anúncio como "pardo". Dois anos depois, o procurador e tio do falecido, Antônio Lopes Braga, usou o termo "mulato atapoiado" para identificar o mesmo Tristão ( $O$ Catechista, 14/03/1869; $O$ AMAZONAS, 3/09/1870). Na realidade, o que as listas de matrícula e de emancipação, bem como os anúncios de fuga publicados nos jornais deixam ver para o Amazonas é que a escravidão podia ser identificada com qualquer um que não fosse branco.

Nesse contexto, o fator miscigenação não pode ser desprezado. Desde o período colonial, os contatos entre indígenas e africanos resultaram em misturas tanto no âmbito biológico quanto no campo cultural. Africanos e índios trabalhavam juntos em várias atividades. Aliavam-se com motivações variadas. Por vezes, essas relações ultrapassavam a criação de mocambos e possibilitavam as uniões consensuais ou mesmo os casamentos legítimos, mesmo na escravidão. O tapuio Celestino Raimundo da Silva foi processado em dezembro de 1863 por tentar matar com um machado a sua mulher, escrava de João José Ferreira. ${ }^{5}$

Essa particularidade torna Manaus uma cidade escravista diferente no Brasil, pois predominantemente multiétnica, ao contrário de cidades como Recife, Bahia e Rio de Janeiro, cujo número muito superior de africanos permitia que um fugitivo passasse despercebido entre tantos libertos, quando a presença indígena já havia sido sobrepujada

\footnotetext{
${ }^{4}$ A ausência de práticas endogâmicas no Brasil possibilitou que filhos, netos e bisnetos de escravas e brancos também fossem escravos, mesmo sendo reconhecidos como brancos ou "praticamente brancos". Segundo ALENCASTRO (1997), isso se deve a um motivo simples: "seguindo a norma do direito romano, o direito imperial brasileiro prescrevia que o estatuto do filho seguia o estatuto da mãe: o filho da escrava nascia escravo.

${ }_{5}^{5}$ Ofício n. 778 da Secretaria de Polícia do Amazonas de 24 de Dezembro de 1863 para o presidente da província Dr. Sinval Odorico de Moura. Livro n. 05 da Secretaria de Policia de 1863.
}

Revista Eletrônica da ANPHLAC, ISSN 1679-1061, n. 16, p. 26 - 56, Jan./Jul. 2014. http://revista.anphlac.org.br 
pelos africanos. Na mesma época, o casal Agassiz tinha dificuldades de traduzir as características fenotípicas da população de Manaus. Diziam ser raro encontrar em Manaus uma pessoa que fosse "absolutamente de pura raça negra" e recorriam aos termos pouco precisos para estabelecer os graus de negritude da população: "mas veemse numerosos mulatos, mamelucos, como chamam os mestiços de índio e negro" (AGASSIZ, 1975, p. 230 e 270).

Nessas condições, Manaus tornava-se, enquanto cidade multiétnica, um abrigo para os fugitivos. O universo social complexo confundia (e conformava) paisagens e personagens comuns - para desespero dos agentes policiais e para a "ação da justiça". Em suma, muitos fugitivos desapareciam na diversidade de matizes étnico-raciais.

Por isso, os movimentos da escravaria preocupavam cada vez mais as autoridades provinciais. Em outras áreas urbanas também se pode verificar a configuração dessas paisagens sociais complexas criadas pelas práticas dos fugitivos, reinventadas no cotidiano, servindo para proteção de desertores e fugitivos. Em Vila Bela da Imperatriz, por exemplo, o escravo Maximiano José, "mulato, 30 anos, sem barba, alto, oficial de alfaiate" vivia fugido há mais de dez meses no "Quarteirão do Mocambo", um dos distritos da Vila, para onde várias diligências haviam sido enviadas a fim de captura-lo. ${ }^{6}$ Esses lugares constituíam o típico "campo negro": lugar de conflitos, solidariedades e proteção que marcavam o cotidiano escravista (GOMES, 2006, p. 233).

Rotas de fugas, ajuntamentos e mocambos suburbanos revelam as agências e lógicas culturais de africanos e descendentes na construção de espaços de socialização entre fugitivos, desertores, amocambados, libertos, índios. Misturando solidariedades e conflitos, índios e negros escapavam das ações "civilizatórias" e da ordem escravista, preservando modos tradicionais de vida e reconstruindo territorialidades. No entanto, esses novos espaços não perdiam os vínculos com as realidades urbanas. As redes mantinham-se conectadas e em permanente atuação, principalmente pelas trocas mercantis: protegendo, apoiando fugas, ocultando informações das autoridades sobre rotas e localidades de refúgio, abrigando desertores e fugitivos (GOMES, 2005; FUNES, 1996).

\footnotetext{
${ }^{6}$ Ofício da Delegacia de Polícia de Vila Bela da Imperatriz de 3 de Novembro de 1862 para o Chefe de Polícia da Província Dr. Caetano Estelita Cavalcante Pessoa. Livro de Ofícios da Secretaria de Polícia de 1862. Arquivo Público do Estado do Amazonas.
}

Revista Eletrônica da ANPHLAC, ISSN 1679-1061, n. 16, p. 26 - 56, Jan./Jul. 2014. http://revista.anphlac.org.br 
Em março de 1864, o senhor Manoel Thomaz Pinto rogava aos inspetores de quarteirão a captura de sua "preta escrava de nome Izabel" (O Catechista,26/03/1864). A escrava fugiu e foi vagar pelos subúrbios. Não era a primeira vez que o Coronel Manoel Pinto solicitava a atuação da polícia. Em janeiro do mesmo ano, a fujona tinha sido presa por ordem do delegado de polícia da capital "à requisição de seu senhor" ( $O$ Catechista, 30/01/1864). Pelos subúrbios andava Maria Salomé até ser presa por "fugida". Circulando pela cidade, construindo rotas e esconderijos, comunidades urbanas de fugitivos e vagamundos se formavam e davam trabalho aos Inspetores de Quarteirão e policiais da cidade (Estrella do Amazonas, 19/09/1860).

Nas décadas de 1860 e início de 1870, ao mesmo tempo em que os fugitivos circulavam pela capital, crescia a demanda das elites proprietárias por comprar, alugar, dispor da mão de obra escrava. Nesse momento, é visível o aumento de anúncios publicados para alugar (estes mais frequentes) e vender escravos nos jornais. Os escravos alugados ficavam sob a responsabilidade dos locatários como se deles fossem, sujeitos às mesmas relações de obrigações mutuas (cuidados com alimentação, vestimenta e descanso dos escravos) as quais estavam ligados aos seus proprietários. $\mathrm{O}$ valor do aluguel era pago diretamente ao proprietário locador ou, se fosse o caso, às agências que acresciam um valor de comissão pelo serviço de intermediação (SOARES, 1988, p.137). As tipografias, tabernas e casas de comércio frequentemente ofereciam escravos para aluguel, como estes do Estrella do Amazonas:

Aluga-se uma escrava, própria para o serviço de uma casa de família; quem precisar dirija-se a esta tipografia que se lhe dirá quem deve tratar (Estrella do Amazonas, 06/04/1861)

Precisa-se de uma mulher escrava ou forra, para o diário de uma casa de pouca família: quem estiver nesta circunstância dirija-se a taberna na travessa da Olaria para tratar do ajuste (Estrella do Amazonas, 27/10/1858).

Para fins de comparação, os estudos sobre a escravidão urbana no Rio de Janeiro do século XIX podem iluminar algumas questões para o mesmo fenômeno em Manaus. Naquela província, cativos eram enviados às ruas com obrigações e tarefas estipuladas previamente. Ao fim do dia os escravos entregavam determinada quantia de seus rendimentos, negociadas a princípio, que variavam de acordo com as atividades realizadas ou segundo os tipos especializados dos serviços. Por exemplo, os serviços

Revista Eletrônica da ANPHLAC, ISSN 1679-1061, n. 16, p. 26 - 56, Jan./Jul. 2014. http://revista.anphlac.org.br 
industriais (ferreiros, oleiros, costureiras) valiam bem mais no mercado. Os pagamentos podiam realizar-se semanalmente e, em alguns casos, mensalmente. A autonomia e a liberdade de que gozavam os escravos não significava uma vida menos difícil. Por vezes, os negros de ganhos possuíam dupla jornada de trabalho, sendo uma na rua e a outra nos serviços das casas de seus senhores, especialmente se estes fossem menos abastados (SOARES, 1988, pp.137-138). ${ }^{7}$

Para os escravos, alugar serviços no âmbito doméstico, nas obras públicas ou pelas ruas como "negros de ganho", foi uma estratégia eficaz para acumular alguns trocados. Entre o valor previamente estipulado a ser repassado ao senhor e a efetiva arrecadação dos dias de trabalho do escravo havia uma margem de diferença que consistia em capital acumulado, conhecido como pecúlio. Juntar seus trocados era uma prática bastante comum entre os escravos e apenas foi legalizada como direito pela lei de 28 de Setembro de 1871. Com este dinheiro muitos chegavam a morar em residências distantes da casa senhorial, alugadas em pensões ou moradias populares. O pecúlio penosamente conquistado permitia maior autonomia aos escravos para gerir seus próprios destinos, construir seus próprios arranjos de moradia e, no limite, comprar a própria liberdade (REIS, 1989, p.17).

Obviamente, viver sobre si significava, ao revés, viver sob maior suspeição e vulnerabilidade. No dia 27 de maio de 1868, o Jornal do Rio Negro noticiou os procedimentos de investigação policial levados à cabo pelo Chefe de polícia para descobrir o autor do crime de roubo sofrido pelo fogueteiro Sebastião. O escravo Manoel passou a ser o principal suspeito do crime. Primeiramente, porque o cativo havia sido preso dias antes por ter entrado disfarçado na casa do cidadão Manoel Antônio Lessa. Segundo, e o mais incriminador para os policiais, Manoel mantinha uma "amásia" sua residindo em uma "casa alugada por 6 mil réis" defronte à casa em que morava o fogueteiro roubado. Foi o suficiente para recolhê-lo à cadeia (Jornal do Rio Negro, 27/03/1868).

\footnotetext{
${ }^{7}$ As atividades vários trabalhos ocasionais podiam beneficiar os senhores de várias maneiras: "o mestre artesão que enfrentava a queda das encomendas teria um retorno financeiro com o trabalho de seus escravos, e assim evitar o desastre financeiro, escapando à crise; um senhor que estivesse em dificuldades mas ainda sem disposição de dar o passo final de vender seus escravos poderia chegar a um arranjo em que, sempre que um escravo realizasse trabalho ocasional, ficasse com parte do ganho, embora, o senhor ficaria isento de maiores obrigações de fornecer abrigo, comida e roupas." (RUSSEL-WOOD, 2005, p. 64).
}

Revista Eletrônica da ANPHLAC, ISSN 1679-1061, n. 16, p. 26 - 56, Jan./Jul. 2014. http://revista.anphlac.org.br 
Os arranjos de moradia dos escravos no Rio de Janeiro revelam que muitos homens libertos e escravos usaram as habitações alugadas. Principalmente aqueles que desempenhavam serviços urbanos. Situação diferente viviam os escravos de serviços domésticos, que geralmente habitavam a casa do senhor. Morar em localidades distantes, longe fisicamente da residência senhorial (e da própria figura do senhor) era uma forma de exercer autonomia, da mesma forma que ampliava a possibilidade de reconstrução de laços identitários e familiares. Por vezes, os cortiços e estalagens localizavam-se em áreas centrais da cidade o que facilitava aos cativos a conquista de trabalho. Em Manaus não era diferente, já que existiam na área do Tamaracá, área central, casas e espaços alugados para escravos. Contudo, muitos senhores respeitavam esse exercício de autonomia de moradia do cativo como uma maneira eficaz de controla-los, diminuindo as tensões em suas relações - numa realidade diferente da escravidão rural e específica do mundo urbano. A figura do Estado é fundamental nesse processo, pois respaldava (ou não) estes arranjos de moradia. Agentes policiais e inspetores de quarteirão eram frequentemente acionados para preencher o vácuo social no controle dos cativos que viviam longe dos senhores no espaço urbano (SANTOS, 2006, p.148-151).

Corria pelos jornais da cidade em meados dos anos de 1870, um apelo à polícia para que se tomassem as "providencias necessárias" contra um constante ajuntamento de escravos vendedores. Eram acusados de atentar contra a "honra da publica moralidade". Segundo o noticiário do Catechista, em toda e qualquer hora, quer fosse dia quer fosse noite,

principalmente das 6 as 9 desta, juntam-se nas rampas em frente às casas do negociante Antônio Joaquim da Costa \& Irmão, nas pontes, e outros lugares, troças de vendedeiras e outras desocupadas que de envolta com marinheiros, escravos dão bem triste exemplos de moral. As palavras obscenas são comuns nas bocas dessas assembleias e ouvem-nas todos os que por necessidade ou recreio passam nesses lugares (O Catechista, 16/07/1870).

Nos jornais do período, assim como nos códigos de posturas municipais, são frequentes os comunicados sobre os horários permitidos aos escravos para circularem pela cidade. O subdelegado suplente de Manaus, o senhor José Miguel de Lemos, informava aos cidadãos em maio de 1861 "que não é permitido andar pelas ruas desta capital depois das 3 horas da noite os escravos, sem bilhete de seus senhores e os

Revista Eletrônica da ANPHLAC, ISSN 1679-1061, n. 16, p. 26 - 56, Jan./Jul. 2014. http://revista.anphlac.org.br 
marinheiros de bordo dos vapores, sob pena de serem recolhidos" (Estrella do Amazonas, 01/06/1861).

Circulando pelas novas pontes, praças, rampas, tabernas, e entre outros lugares da cidade, escravos e escravas vendiam os seus produtos, juntavam suas quantias e recriavam espacialidades. Mais do que isso, forjavam uma cultura urbana que impunha limites aos interesses das elites senhoriais e aos valores de "civilização e progresso" sistematicamente cultivados na província. Em larga medida, a prevalência dessas atividades autônomas na cidade pode ter interferido no processo de desagregação da instituição escravista (MACHADO, 1988, p.149). Em janeiro de 1871, o Catechista publicava uma nota dirigida às autoridades policiais: "É muito conveniente que a polícia preste sua atenção para os cambembes que existem alugados para os escravos na travessa da matriz e na de Tamaracá". 8

Com efeito, as experiências africanas trazidas por afrodescendentes na diáspora sofriam suas atualizações em vários espaços da cidade, especialmente aqueles ligados à habitação e moradia. Na semana seguinte à denúncia dos "cambembes" alugados aos escravos, o mesmo jornal ameaçava "a certo janota que a pouco chegou á esta cidade" de "escovar-lhe as costas com um chicote de couro cru" e envia-lo, como que expurgado, para "passear a costa d'África", um pequeno bairro de Manaus habitado em grande parte por trabalhadores de origem africana, os chamados "africanos livres" ( $O$ Catechista, 15/01/1870). Em todos os lugares de Manaus novos territórios culturais foram forjados e resignificadas e sugerem, no limite, a formação de comunidades escravas com práticas, símbolos e significados reunidos em torno da manutenção de experiências africanas. $^{9}$

Os trabalhadores de origem africana que serviam em diversas obras publicas também estavam sob suspeição das autoridades policiais. O presidente da província Manoel Clementino Carneiro da Cunha orientava o chefe de polícia da província a "expedir convenientes ordens afim de que os africanos livres, que forem encontrados nas ruas desta cidade depois das oito horas da noite sejam todos detidos na cadeia até

\footnotetext{
${ }^{8}$ É interessante notar que o nome dado aos dois lugares alugados pelos escravos faz referencia a uma localidade do interior de Angola, chamado Cambembe, "às margens do rio Cuanza e Pundo Andongo, antiga capital do Reino do Ndongo". Além de significar, também, trabalhadores assalariados que trabalhavam junto com os escravos (REGINALDO, 2005, p.49); Sobre a outra possibilidade de significado para a palavra Cambembe, ver: (AULETE, 1925) Disponível em: http://www.auletedigital.com.br

${ }^{9}$ Sobre a presença de Africanos livres no Amazonas (SAMPAIO, 2005).
}

Revista Eletrônica da ANPHLAC, ISSN 1679-1061, n. 16, p. 26 - 56, Jan./Jul. 2014. http://revista.anphlac.org.br 
serem apresentados ao diretor das obras publicas" (Estrella do Amazonas, 26/10/1861). A finalidade explicita dessas determinações se depreende da fala do então presidente: mesmo não sendo "operários da melhor qualidade", supriam a "necessidade de trabalhadores" e davam "andamento ao serviço" (AMAZONAS, 1862, p.20).

Um ano depois, a mobilidade da escravaria e as formas pelas quais os senhores deveriam gerencia-la eram preocupações ainda presentes nas ações das autoridades da província. Dessa maneira, o subdelegado alertava:

Os escravos que forem encontrados de noite desde o toque de recolher até o da alvorada, amontados de seus senhores, sem bilhete destes, datado, e assignado, com declaração do nome do escravo, ou sem lanterna, facho, ou archote, serão conduzidos de baixo de prisão. (Estrella do Amazonas, 8/02/1862).

Em tom debochado, o Estrella do Amazonas publicou um "edital burlesco", extraído de um folheto de nome Popular, contendo algumas prescrições aos cidadãos de Manaus. No artigo $4^{\circ}$, dizia o seguinte: "Os negros que divagarem sem bilhete de seus senhores serão surrados depois das 10 horas da noite, com açoites de bacalhau em publico e raso: multa de 10\$000, se não quiserem levar a dose" (Estrella do Amazonas, 15/09/1860). Todas essas notificações, ainda que em tom de piada, têm a finalidade reforçar a lógica de exclusão social e de manter em funcionamento uma série de práticas de controle não só em relação à escravaria, mas também sobre os demais indivíduos que passam a compor o conjunto de trabalhadores das cidades e espaços urbanos da província do Amazonas. Indígenas, tapuios, africanos livres e escravos configuram um universo étnico bastante multifacetado e que precisa ser "ordenado", subalternizado, controlado.

Portanto, a cidade instituída pelos negros era também uma cidade-esconderijo, com características bastante particulares. Uma cidade em pleno processo de modificações urbanas, caudatárias da expansão da economia gomífera, que resultou num outro processo de complexificação social, uma vez que a migração de diferentes sujeitos de diferentes culturas ampliaram os recortes étnicos da paisagem social e urbana de Manaus. Ademais, o gradiente de cores associadas à condição escrava era demais amplo e, por isso mesmo, havia, certamente, uma imensa dificuldade em relacionar cor e escravidão no Amazonas. Como resultado da complexificação urbana e

Revista Eletrônica da ANPHLAC, ISSN 1679-1061, n. 16, p. 26 - 56, Jan./Jul. 2014. http://revista.anphlac.org.br 
social, as reuniões entre escravos, africanos, vendedeiras e marinheiros, tornaram-se alvo constante da suspeição policial.

Não por acaso, o número de prisões indicado nos movimentos da cadeia revela uma evolução crescente no período final da década de 1850 e início de 1860 . O cotidiano que se revela através das prisões, as experiências compartilhadas entre escravos, índios e africanos nesse movimento de repressão, bem como os efeitos sociais daí decorrentes serão tratados mais à frente. No entanto, é possível antecipar que além das prisões por crimes, suspeitas e indagações, aspectos estes frequentes das ações policiais, havia também os "recolhimentos" para formar os quadros das forças públicas e encerrar as fileiras do exército, como também os recrutas para os corpos de trabalhadores.

Nesse contexto, fugir era ainda mais arriscado. A vida em fuga estava sujeita à constante perseguição e instabilidades. A atuação policial havia aumentado não somente por conta da preocupação com os possíveis infectados com a epidemia do Cólera, prevenindo os ajuntamentos ${ }^{10}$ de um sem número de doentes, mas também para assegurar que os movimentos de escravos, indígenas, africanos livres, homens pobres, migrantes nacionais e estrangeiros no ambiente urbano não se transformasse em desordem generalizada. O frágil controle social dos trabalhadores tornava-se ainda mais difícil quando circulavam pelas cidades alguns exemplos de "criminalidade": os embriagados, desertores, fugitivos, vadios, briguentos, acoutadores de escravos, entre outros "criminosos".

A ação concentrada das forças públicas no sentido de controlar o movimento da escravaria permanecerá durante todo o século XIX. Quase vinte anos depois, no auge da campanha pela libertação dos escravos e às vésperas da abolição em Manaus, o jornal Abolicionista do Amazonas denunciava a prisão à qualquer pretexto dos cativos. Segundo o noticiário, ainda continuava "como medida correcional a pratica abusiva da detenção de escravos na cadeia desta capital, por tempo indefinido, em consequência de simples requisições de seus pretensos senhores" (Abolicionista, 05/05/1884). Por outro

\footnotetext{
${ }^{10}$ As medidas higiênicas para prevenção contra o Cólera adotadas pela província previa que a polícia deveria zelar pela "limpeza e asseio das ruas, examinar as substancias alimentares que se vendem não excetuando as bebidas, pois que toda a parte, e sempre os mercadores de comestíveis, especulam com as necessidades públicas, vendendo gêneros corrompidos" e, não menos importante, "ordenar para que se façam as fumigações nas prisões, hospitais e outros lugares, onde hajam ajuntamentos e pessoas que vivem em lugares húmidos e mal arejados. Ver: (CANAVARRO, 1862, p. 10).
}

Revista Eletrônica da ANPHLAC, ISSN 1679-1061, n. 16, p. 26 - 56, Jan./Jul. 2014. http://revista.anphlac.org.br 
lado, a recorrente veiculação destas normas e "editais" talvez sinalize a própria ineficácia de tais medidas. No limite, podem desvelar a resistência aos mecanismos de controle social, agenciados por senhores e autoridades publicas, que são as próprias práticas antitéticas de escravos, indígenas e africanos. ${ }^{11}$

Todos estes elementos, que caracterizam a escravidão urbana no Amazonas, trazem um novo problema para a historiografia local. Não é mais possível considerar a construção da cidade de Manaus como produto apenas do conflito existente entre a cidade projetada pelas elites locais, majoritariamente "branca", e as tradições indígenas. É preciso acrescentar agora ao quadro de embates um outro fator: a cidade instituída pelos negros. Sobre Manaus como uma cidade esconderijo cabe dizer o seguinte. Quando o escravo fugia para Manaus encontrava uma cidade em plena expansão, entreposto importante de mercadorias. Pelas ruas, vielas e casas comerciais circulavam toda sorte de pessoas: portugueses, bolivianos, peruanos, venezuelanos, brancos e indígenas. E seguramente estavam ocupados por negros -, africanos ou não, livres ou não -, para a insegurança dos seus "bons cidadãos". Com efeito, a Manaus que era instituída também pelos negros tornava-se cada vez mais um lugar de esconderijo entre subúrbios, travessas, ajuntamentos e casas alugadas.

\section{Matas, cabeceiras e igarapés: refúgio e liberdade.}

Quando não escolhiam os cenários urbanos, os escravos escapavam pelas malhas dos rios, furos e igarapés, escondiam-se pelas matas, como se a fuga fosse mesmo um meio de mimetizar-se. Para se protegerem das autoridades, agentes policiais e outros mais perseguidores, os escravos fugiam para as cabeceiras dos rios, comerciavam com os habitantes dos arredores, mudavam frequentemente de esconderijo deixando somente

\footnotetext{
${ }^{11}$ Edward Thompson sagrou-se como importante historiador social preocupado com as experiências e os conflitos das camadas trabalhadoras da Inglaterra do século XVIII. Em seus estudos, no que concerne ao direito e ao crime, Thompson afirma o caráter complexo da lei como espaço do conflito, de mediação entre os diferentes personagens históricos, analisando as características, a historicidade e lógica própria de seu desenvolvimento no interior da sociedade. Este procedimento analítico garante o mínimo de criticidade sobre o valor moral das motivações e ações dos grupos subalternos, bem como assinala certas dimensões da cultura popular, problematizando a noção de crime. Estas reflexões de Thompson podem esclarecer as complexidades em torno das práticas antitéticas dos grupos marginalizados, relativizando, no caso do Amazonas, as representações em torno da ideia de criminalidade formuladas por suas elites dominantes. Ver, entre outros: (THOMPSON, 1987; 1998).
}

Revista Eletrônica da ANPHLAC, ISSN 1679-1061, n. 16, p. 26 - 56, Jan./Jul. 2014. http://revista.anphlac.org.br 
os rastros de pequenas cabanas abandonadas para recriar refúgios em outros lugares percorrendo o interior do vale e das matas amazônicas.

Nesse aspecto, os mocambos e quilombos da Amazônia eram diferentes daqueles de outras localidades do Brasil. Não se formavam grandes e estáveis quilombos, mas pequenos grupos de fugitivos, migrando permanentemente, modificando e reconstruindo as pequenas comunidades que se organizavam (com base nos grupos de parentesco e companheiros de fuga). Essa itinerância não significava que os grupos de fugitivos estivessem desconectados da sociedade, pois os contatos e as trocas mercantis com as vilas, os povoados e fazendas eram constantes. Mesmo porque os pequenos grupos possuíam maior mobilidade facilitando o desmanche da comunidade e a nova fuga antes mesmo que as diligências de captura pudessem se aproximar (GOMES, 2006, p. 290).

Trata-se, por assim dizer, de fugas miméticas, cuja característica principal é a de manter-se invisível, quase camuflados, usando o meio natural como principal aliado. Conhecer o ambiente natural era questão fundamental para os fugitivos, sua sobrevivência e reprodução de suas comunidades enquanto organização social diferenciada. A caça, a pesca, a extração dos produtos, além das atividades de agricultura alimentar e pequenas manufaturas serviam para as trocas mercantis e a sobrevivência no grupo - nem que fosse para agradar um viajante com frutas e proteger a comunidade da delação. O historiador Eurípedes Funes nos diz o seguinte sobre a relação entre natureza, mocambos e cultura:

Conhecer o meio ambiente era fundamental para o sucesso das fugas, já que a natureza tornava-se cúmplice natural. No tempo das cheias, capinzais crescem às margens dos lagos, formando tapagens, obstruindo os igarapés que os interligam entre si os rios, dificultando a passagem camuflando os caminhos. Estabelecidos acima das corredeiras e cachoeiras, os quilombolas interpunham obstáculos naturais entre eles e seus perseguidores (FUNES, 2009, p.150).

Por outro lado, é importante ressaltar que muitos desses fugitivos encontravam condições favoráveis para a criação de comunidades, micro sociedades, autossustentáveis. Pelos furos e igarapés os escravizados construíam mocambos e neles cultivavam produtos que poderiam atender às necessidades mais prementes. Trocando objetos furtados dos senhores ou vendendo os produtos dos pequenos roçados para

Revista Eletrônica da ANPHLAC, ISSN 1679-1061, n. 16, p. 26 - 56, Jan./Jul. 2014. http://revista.anphlac.org.br 
indígenas, desertores e regatões, os fugitivos também juntavam seus trocados sobreviviam física e socialmente.

Seguindo pelo rio Amazonas, Paul Marcoy encontrou "dois velhos de pele escura" que viviam há tempos refugiados no interior da floresta. Pelo que esclarece o viajante, o casal de negros possuía um serviçal, um "índio tapuia”, que lhes ajudava no cultivo de uma pequena plantação de alimentos cujos excedentes eram trocados com os moradores daquela localidade por sal, algodão, veneno para caça e instrumentos de pesca. Marcoy, noites antes, havia se deparado com "um casebre" rodeado por uma pequena varanda que servia de horta, habitada por "três desertores (...) que viviam em paz e segurança com suas mulheres pardas de narizes achatados” (MARCOY, 2006, 107119).

Não é por acaso que mais da metade dos escravizados fugia no período de fevereiro à julho (57\%). As fugas acompanhavam os ciclos de cheia e vazante dos rios. Os escravos estavam atentos aos movimentos dos rios, quando os incontáveis canais e igarapés estavam conectados, facilitando a navegação. É nesse momento que se podia tomar as "montarias", "cobertas" ou canoas para fugir. Este período de cheias dos rios da Amazônia coincide com o inverno, com o tempo da colheita da castanha e também com as festas natalinas e juninas (FUNES, 1996, p.474). Os tempos de festa e tempos de cheia ajudavam a despistar.

Refugiando-se pelas margens dos rios, como no rio Madeira, os escravos certamente encontrariam os "imensos e tão famosos lagos onde em todo ano se podem apanhar milhões de tartarugas, de peixe bois, pirarucus, tambaquis e muitos outros". Certamente, um grande atrativo para os fugitivos. Aliás, os dados apresentados pelo presidente da província em 1861, demonstram um crescimento significativo na economia de Borba e atribuía este resultado ao "desenvolvimento que vão tendo no rio madeira o comercio, e a indústria da extração dos produtos naturais, em que ele abunda" e ao crescente comércio de "importação de gêneros procedentes da republica peruana" (AMAZONAS, 1860, p. 18-20; 1864, p. 35).

No dia 5 de maio de 1882, constava no Jornal do Amazonas o anúncio da fuga de um escravo chamado Jorge, "mulato, pouca barba e muito falante", propriedade do capitão da Guarda Nacional Pedro Antônio de Souza. Fugiu à noite, "conduzindo uma pequena montaria", de um lugar nomeado "Gavião" no rio Juruá, área de intensa

Revista Eletrônica da ANPHLAC, ISSN 1679-1061, n. 16, p. 26 - 56, Jan./Jul. 2014. http://revista.anphlac.org.br 
circulação de embarcações por conta da produção da borracha (Jornal do Amazonas, 05/05/1882). Em tempo de cheia, também, fugiram da cidade do Pará os escravos “João, mulato de idade de 34 anos pouco mais ou menos, cabelo pouco crespo, olhos pardos, pouca barba e descarnado do rosto" e Alexandrina, "preta, idade de 26 a 28 anos pouco mais ou menos, alta e de boa figura, olhos grandes e pretos, nariz chato, e pés também crescidos". Segundo desconfiava seu senhor, os dois cativos decidiram "subir o rio Amazonas com destino ao mencionado rio e lugar onde foi criado o referido mulato" (Estrella do Amazonas, 16/04/1856).

João e Alexandrina viveram em liberdade por mais de dois anos até que foram capturados nas proximidades do destacamento de Chibarú, exatamente no rio Negro. A unidade militar em que os dois escravos foram capturados tinha sido criada em janeiro de 1857. A epidemia do cólera e o "flagelo da febre amarela" se estendeu pelo Rio Negro, assolando as localidades de "Airão até Santa Izabel, atacando principalmente esta povoação e a vila de Barcellos". Ao chegar "ao rio e lugar onde foi criado", João mulato e sua companheira não encontraram condições de saúde satisfatórias para ali residirem.

Exatamente pela falta de "salubridade" nas comunidades e povoações daquela região do rio Negro que se criou um destacamento no lugar chamado "Chibarú", na costa de Lama-longa, acima da extinta povoação que carregava esse nome. Chibarú foi planejada para servir de entreposto aos moradores de Tomar e Santa Izabel e, pelo que acreditava o então presidente João Pedro Dias Vieira das terras deste novo destacamento, "pela sua fertilidade e extensão, abundancia de peixe e caça, salubridade do sitio", preparar os fundamentos de uma povoação, cuja prosperidade a posição geográfica garantiria.

Não é surpresa que João e Alexandrina tenham encontrado refugio nas proximidades de tão próspero lugar. E, tão logo instalados, sob as ordens do capitão da guarda policial, Francisco Gonçalves Pinheiro, os novos moradores já esperavam autorização para empregar materiais e trabalhadores na construção de uma Igreja e um Quartel: "os alicerces de uma futura povoação para entreposto do alto e baixo rio negro" (Estrella do Amazonas, 04/03/1857).

Quando o casal de fugitivos foi preso, Alexandrina ficou no distrito de Chibarú para ser vendida, e o escravo João foi remetido à delegacia da capital. Permaneceu ali

Revista Eletrônica da ANPHLAC, ISSN 1679-1061, n. 16, p. 26 - 56, Jan./Jul. 2014. http://revista.anphlac.org.br 
sob custódia durante mais ou menos um mês. Ainda preso, conheceu na cadeia um escravo de nome José Paulino, apelidado de Macaçar, com quem escapou da prisão em uma "montaria toda pintada de verde" que "dizem pertencer ao mestre carpinteiro Funfão”. Antônio José Pereira Carneiro, senhor de João, suspeitava que os fugidos tivessem seguido "para o Rio negro, ou Madeira onde já residiu em fuga o dito mulato José Paulino, com nome suposto de Antônio Paulino.” (Estrella do Amazonas, $22 / 05 / 1858)^{12}$

\section{Africanidades latino-americanas na Amazônia e espaços transnacionais.}

Se buscassem refúgio nos lagos e afluentes do Madeira certamente encontrariam uma região abastada tanto pelos recursos naturais quanto pelo crescente comércio que se desenvolvia através da navegação, das canoas de regatão, nos muitos tráficos para o Mato Grosso e para os estados estrangeiros. Seguindo pelo Rio negro, estariam como o preto crioulo de nome Pedro, oficial de carpina, e o mulato atapoiado chamado Aprígio, padeiro, que fugiram em uma montaria grande pretendendo subir o rio Negro para a "Hespanha", Estado estrangeiro de Nova Granada (Estrella do Amazonas, 03/03/1858) Ou como Luiz, nascido no Maranhão, escravo da cor preta de 42 anos, "bigodes cerrados, com falta de alguns dentes da frente", que fugiu de Vista Alegre no rio Purus, remando rio acima embarcado numa quebrada montaria com "destino, talvez de refugiar-se com algumas das Repúblicas vizinhas: Bolívia, Venezuela ou outra” (Diário do Amazonas, 14/08/1873). O senhor de Luiz pedia às autoridades policiais e comandantes dos postos militares de fronteira - de Chibarú, inclusive - a captura do escravo antes que ele atravessasse a fronteira internacional.

As fugas na região de fronteira internacional revelam outros destinos $\mathrm{e}$ estratégias mais amplas. Estes territórios foram alvos permanentes da preocupação das autoridades brasileiras. A maioria dos países limítrofes, nos seus respectivos processos de independência em relação à colonização espanhola, proclamou o fim do tráfico

\footnotetext{
$12 \mathrm{O}$ apelido Macaçar, pode se referir à uma cidade do Timor Leste, chamada Pante Makasar, que literalmente significa "ponte dos macassares" por causa dos negociantes portuários desta localidade do oriente asiático, habitada por povos islamizados. Este lugar foi colonizado por portugueses desde a primeira metade do XVI, fazendo parte de um conjunto de ilhas do Timor com importância estratégica nas rotas de comércio e navegação de especiarias e escravos, a par de sua importância econômica enquanto fonte riquíssima de sândalo. Ver: (LOUREIRO, 2001, pp. 143-155).
}

Revista Eletrônica da ANPHLAC, ISSN 1679-1061, n. 16, p. 26 - 56, Jan./Jul. 2014. http://revista.anphlac.org.br 
negreiro e a abolição da escravidão. Em alguns países, como a Bolívia, prevaleceu a conduta de asilar cativos brasileiros. Além dos evidentes problemas para a diplomacia brasileira envolvendo a atuação internacional na defesa da propriedade dos seus cidadãos, havia, também, a inquietude das elites brasileiras com o contato dos grupos de fugitivos com as ideias revolucionárias ligadas à liberdade e ao fim da escravidão que circulavam por toda a América. Embora as fugas internacionais ainda sejam um tema pouco frequentado pela historiografia, existem relatos importantes sobre os contatos de quilombolas, mocambeiros, desertores e fugitivos nas zonas de fronteira da Amazônia Caribenha, construindo suas próprias territorialidades à revelia dos tratados internacionais.

Desde o século XVIII, as autoridades coloniais das Capitanias do Rio Negro e do Grão-Pará temiam que os seus escravos entrassem em contato com as informações sobre as revoluções que ocorriam no Caribe e na Europa. Tais capitanias divisavam território com as Guianas Francesas, mas também com territórios sob domínios espanhol, inglês e holandês e, entre Caiena e o Grão-Pará e Rio Negro havia uma constante movimentação de escravos fugidos e comunidades quilombolas (GOMES, 1996, p.46). No mesmo passo que se tentava estabelecer na região vários tipos de exploração econômica, construía-se uma barreira humana contra holandeses, ingleses, franceses e espanhóis. É nesse período que se desenrolam vários tratados internacionais com vistas a estabelecer tais limites, mas que tomavam outros contornos diante do intenso tráfego de indígenas, escravos fugidos e marinheiros desertores, configurando um "complexo cenário de disputas coloniais, principalmente nas áreas do Rio Negro, Madeira, Solimões, Rio Branco, Tapajós e Amapá” (GOMES, 2004, p.46)

Com efeito, os escravizados da região amazônica estiveram atentos à conjuntura política internacional. Os fugitivos teciam redes que acabam por formar não apenas um cenário de circulação de informações sobre as discussões em torno do fim do tráfico, a abolição da escravatura no território francês e nas colônias francesas, ou sobre os levantes de escravos que aconteciam em outras colônias nas Américas, sem esquecer as lutas de independência na Venezuela; mas também elaboravam uma rede de

\footnotetext{
${ }^{13}$ GOMES, Flavio. Etnicidade e fronteiras cruzadas nas Guianas. Estudos Afro-americanos Virtual, $\mathrm{n}^{\circ} 2$, 2004, p.46.
}

Revista Eletrônica da ANPHLAC, ISSN 1679-1061, n. 16, p. 26 - 56, Jan./Jul. 2014. http://revista.anphlac.org.br 
intercâmbios entre mercadores, mocambeiros e etnias indígenas diversas na Amazônia Brasileira e suas fronteiras (BEZERRA-NETO, 2001, p.83).

É certo que este pano de fundo trazia à tona lembranças preocupantes para as elites brasileiras. A circulação nas fronteiras, o contato que as gentes de cor tinham com ideias revolucionárias e grupos desertores, as relações entre grupos quilombolas do Suriname e comunidades de fugitivos do Brasil significavam a possibilidade de levantes de dimensões alarmantes. No contexto de independência do Brasil, por exemplo, a experiência revolucionária do Haiti (quando os escravos tomaram o poder, assassinaram os senhores e estabeleceram sua própria republica) penetrava de forma perturbadora o imaginário das elites senhoriais, de políticos brasileiros e portugueses. Outras rebeliões escravas no Atlântico alimentavam a memória temerosa daqueles que viviam enfurnados em palácios e casas senhoriais. Basta citar algumas: as revoltas na Virgínia (1800 e 1831) e na Carolina do Sul (1822); na Venezuela (1795); em Cuba (1795 e 1812); no Caribe inglês, as rebeliões de Barbados (1816), de Demerara (1823) e da Jamaica (1831). No Brasil, o pânico se alastrou com o ciclo de revoltas na Bahia e a movimentação dos Malês (1835). ${ }^{14}$

No Amazonas, a preocupação com o movimento dos escravos, com a fuga e com o contato entre fugitivos, desertores e criminosos de toda sorte, especialmente se tais exemplos de rebeldia ocorressem na região de fronteira, também era informada por este "medo branco" (CHALHOUB, 1988) que pairava por todo o Brasil escravista. Não se pode esquecer o verdadeiro pavor que as autoridades da região sentiam ante a menor lembrança dos "tempos calamitosos de 1831 a 1840" da Cabanagem (AMAZONAS, 1852, p.6). A memória perturbadora das duas décadas em que escravos, libertos e as classes subalternas como um todo estiveram em "anarquia latente ou explicita" no Grão Pará causava nas elites regionais um pânico que deve ser dimensionado como parte integrante das preocupações políticas e diplomáticas das autoridades locais, sobretudo quanto aos limites territoriais da província - um passado ainda presente na experiência desses sujeitos.

A Cabanagem certamente foi experiência fundamental na vida das gerações seguintes. Só na Comarca do Alto Amazonas o número de mortos estimado é de 60 mil pessoas. Por outro lado, a Cabanagem foi um movimento "tão vasto e complexo que só

\footnotetext{
${ }^{14}$ Sobre algumas dessas rebeliões ver as seguintes obras: (GENOVESE, 1983); (COSTA, 1998).

Revista Eletrônica da ANPHLAC, ISSN 1679-1061, n. 16, p. 26 - 56, Jan./Jul. 2014. http://revista.anphlac.org.br
} 
pode ser entendido dentro de uma perspectiva internacional" na medida em que ele ocorreu em um contexto de "fronteira com as Guianas e o Caribe de um lado e com o mundo hispânico que se tornava independente de outro". A revolução cabana não só aumentou o contato e as trocas de alimentos e armas no ir e vir das fronteiras com o mundo inglês, holandês, francês e hispânico, como também intensificou a circulação de “ideias e práticas revolucionárias” (RICCI, 2008, p.91; HARRIS, 2010).

No contexto de repressão às rebeliões escravas em todo o Atlântico, o movimento abolicionista britânico, em especial a Anti-Slavery Society, passou a atuar na região do Caribe procurando divulgar ideias de libertação, de "incensar os negros, comover a opinião pública e acelerar o fim da escravidão" (PARRON, 2011, p.29). Anos depois de derrotada a revolução cabana, quando muitos negros fugiam do Pará para o Rio Negro, na Guiana Francesa, a escravidão seria abolida, em 27 de abril de 1848. Na mesma época, o presidente da província do Grão-Pará solicitava instruções ao Ministério dos Negócios Estrangeiros sobre as medidas que se deveria adotar "com o fim de evitar as fugas de escravos dessa Província para a Guiana onde foi abolida a escravidão". As preocupações do presidente do Pará e os receios da Secretaria do Ministério surgiram com

as notícias recebidas de quem um mulato natural de São Domingos, fora aquela cidade revestido à caráter de emissário das sociedades que trabalham pela liberdade dos escravos, o qual unindo-se com outros agentes das mesmas associações, partiu com eles para a Inglaterra para de lá se dirigirem à Guiana com o projeto de penetrarem no Brasil. $^{15}$

Percebe-se, nesse trecho, os bumerangues africanos, formulação que sugere uma circulação de ideias e trocas de experiências das rebeliões e revoltas escravas nas Américas que seguiram até aos trabalhadores ingleses através na navegação atlântica e que retornaram ao mundo caribenho como luta pela abolição e fím do tráfico (LINEBAUGH, 1983, pp. 7-46). Nossa preocupação aqui é menos discutir a existência real (ou não) desses emissários e agentes, do que chamar atenção para as redes que se interpenetram nas Américas e na Amazônia. Essas conexões mantidas entre os fugitivos, as populações indígenas e os quilombolas das Guianas adquiriam significados políticos aterrorizadores para os senhores e autoridades provinciais. A simples

\footnotetext{
${ }^{15}$ Arquivo Público do Estado do Pará. Fundo da Secretaria da Presidência da Província. Caixa 79. Ano: 1841-1849..Ofícios sobre a questão de limites de 16 de Janeiro de 1849
}

Revista Eletrônica da ANPHLAC, ISSN 1679-1061, n. 16, p. 26 - 56, Jan./Jul. 2014. http://revista.anphlac.org.br 
possibilidade de movimentos de fugitivos com rotas para zonas transnacionais, revelam as fugas como resultado estratégico da confluência de consistentes redes de relações sociais não só entre escravos, mas também com indígenas destribalizados, bolivianos, peruanos, venezuelanos, marinheiros desertores, entre outros atores sociais. Movimentos que acabavam por forjar nos seus próprios termos, e sob suas próprias percepções políticas, as definições de liberdade, bem como outros limites para as fronteiras nacionais, na contramão das delimitações impostas pelos tratados e políticas dos Estados Nacionais.

Para se ter uma ideia do quanto estas articulações poderiam gerar um "medo pânico" entre os cidadãos da província, basta citar um caso ocorrido em abril de 1854, quando um escravo do coronel Manoel Thomaz Pinto espalhou entre os habitantes de Manaus ter ele visto um grupo de índios e negros, vestidos com uniformes pretos, armados com paus e facas, escondidos na estrada da Cachoeira Grande, limites da cidade, a aguardar o momento ideal para invadir a capital. A notícia rapidamente se espalhou, a ponto de muitas famílias arrumarem as malas para fugir da cidade. Tanto que o encarregado da presidência, o sr. Miranda, vendo que era "geral o susto das famílias" mandou todo o contingente da guarda nacional, devidamente armado, explorar as matas e cercanias durante o dia inteiro, madrugada adentro (Estrella do Amazonas, 21/04/1854).

Nos jornais encontram-se relatos destes contatos inter-étnicos que vêm reforçar a existência de um processo histórico de comunicação e trocas culturais nas fronteiras, reinventando-as, envolvendo indígenas, escravos fugidos, regatões e os negros do Caribe inglês, francês e holandês. Nos extratos do expediente do governo do mês de maio de 1860, podia-se ler as correspondências do presidente da província com o comandante da fronteira do rio-Branco. O comandante avisava sobre a presença de crioulos do Demerara nas fronteiras do Amazonas fazendo entrincheiramentos no Pirarara. O que parecia mais alarmante ao comandante era a união entre índios e crioulos para, segundo ele, ameaçar a presença do destacamento amazonense na fronteira. O presidente, em resposta, recomendou ao comandante que estabelecesse negociação com os chefes do grupo de índios e crioulos para fazê-los recuar em "tão atentatório procedimento" (Estrella do Amazonas, 05/05/1860).

Revista Eletrônica da ANPHLAC, ISSN 1679-1061, n. 16, p. 26 - 56, Jan./Jul. 2014. http://revista.anphlac.org.br 
Em 1841, as instruções de Duarte da Ponte Ribeiro para as missões diplomáticas do Ministério dos Negócios Estrangeiros afirmavam que a relutância do Congresso e do Governo da Bolívia em restituir os escravos para os proprietários brasileiros tinha a finalidade de "povoar as desertas províncias de Mojos e Chequitos". Em 1859, Duarte Ribeiro acreditava ser inútil os esforços brasileiros no sentido de criar artigos para a devolução de escravos fugidos nos Tratados de fixação de Limites. Isto porque a restituição de fugitivos

Quando concordada fosse com o Governo da Bolívia, jamais se efetuaria, como não se realiza em nenhuma das Repúblicas que a tem convencionado com o Império. A escravidão foi ali abolida desde o nascimento da República; a sua Constituição dá liberdade a todo o escravo que pisar o território Boliviano; e o Código penal em vigor, manda punir com quatro anos de prisão quem entregar, ou mandar fazer entrega a outro Governo, ou a indivíduo particular, um escravo asilado em Bolívia. ${ }^{16}$

Enquanto o governo não entrava em consenso sobre o que deveria ser mais importante na agenda diplomática, a política de proteção e asilo aos escravos, transformando-os em homens livres, continuou firme sobre as tentativas de recuperação dos escravos que fugiam do Brasil (CALDEIRA, 2009, p.159-172). Se esteve correto Duarte Ribeiro em suas avaliações a respeito do desejo boliviano de ocupar as terras desertas do país, os escravos seriam recebidos pelo governo da Bolívia com muita satisfação.

Com o Peru a situação era parecida. O Brasil se via às voltas com o problema da extradição dos criminosos e escravos fugidos. A fragilidade (ou mesmo inexistência) dos acordos sobre a delimitação das fronteiras transformaram a região num cenário de conflitos internacionais. As disputas entre os demais países e as intenções expansionistas que surgiam à reboque dos tratados deixavam as autoridades brasileiras em apreensão. As controvérsias tanto em relação aos limites quanto à restituição dos desertores e escravos criavam uma expectativa de desconfiança em ambos os lados. Porém, a fronteira também passava a apresentar expectativas bem reais de alcance da liberdade ao cruzar os limites para o Peru (BASTOS, 2006, p.6).

\footnotetext{
${ }^{16}$ Pasta A-73. Instruções de Duarte da Ponte Ribeiro para o negociador de um Tratado de Limites do Império do Brasil com a República Boliviana. Missão Diplomática à República da Bolívia, 1860, p. 13. Arquivo da Comissão Brasileira Demarcadora de Limites. Belém. Pará. Ver também: Pasta A-63. Informação ao meu sucessor sobre o estado das relações políticas do Peru e Bolívia com o Brasil relativamente a limites, navegação fluvial, comércio, etc. Lima, 9 de Julho de 1841. Duarte da Ponte Ribeiro, p. 12-13. Belém. Pará.
}

Revista Eletrônica da ANPHLAC, ISSN 1679-1061, n. 16, p. 26 - 56, Jan./Jul. 2014. http://revista.anphlac.org.br 
Assim, toda a região de fronteira estava envolvida em conflitos e disputas envolvendo territórios, controle de riquezas e de força de trabalho. Por outro lado, as comunidades de fugitivos encontravam nesses lugares relativa segurança contra as diligências re-escravizadas que pudessem ser enviadas pelas autoridades provinciais do Amazonas.

\section{Considerações finais.}

Entre lagos, cabeceiras, afluentes, rios, destacamentos, feitorias, pequenas povoações, vilas e matas, os fugidos e mocambeiros faziam circular suas experiências de cativeiro, suas formas de resistência, criavam zonas de trocas culturais e de experiências de liberdade. Estiveram atentos para aquilo que a natureza lhes ofertava e para o crescimento macroeconômico da região. Podiam alimentar microeconomias através das trocas, das vendas ou do simples contato com as populações ribeirinhas.

Em Manaus, muitos fugitivos encontravam uma cidade-esconderijo, multiétnica e em pleno processo de transformação urbana e incremento populacional, ancoradouro do intenso fluxo e circulação de embarcações, mercadorias e, obviamente, de experiências entre as classes subalternas pelos rios da Amazônia.

Dessa maneira, a partir de trajetórias múltiplas e diferenciadas, os fugitivos acabaram por alargar as margens de autonomia e liberdade que as fugas lhes proporcionavam. As migrações constantes daí decorrentes construíam outras fronteiras, ocupadas e controladas pelos grupos amocambados.

As fugas alimentavam o medo entre as autoridades e senhores, medo de ver emergir insurreições articuladas entre negros, índios e outros "criminosos". O fluxo e a circulação de ideias aconteciam nessas redes e trocas, nas canoas que penetravam os sertões amazônicos em busca de refúgio. Embora os temores não sejam suficientes para explicar os processos históricos (GOMES, 2006, p.233) destacar as relações entre o medo e as ações de rebeldia dos escravos nos parece importante para compreender os significados das fugas e, claro, da escravidão no Amazonas. Em suma, o medo, latente ou explícito, de senhores e autoridades provinciais certamente desencadeou uma conjuntura de forte repressão que iria marcar os anos das décadas de 1850-60.

Revista Eletrônica da ANPHLAC, ISSN 1679-1061, n. 16, p. 26 - 56, Jan./Jul. 2014. http://revista.anphlac.org.br 


\section{Referências Bibliográficas.}

AGASSIZ, Luiz e Elizabeth Cary. Viagem ao Brasil, 1865-1866. Belo Horizonte: Ed. Itatiaia; São Paulo: USP, 1875.

ALENCASTRO, Luiz Felipe de. Vida privada e ordem privada no Império. In: NOVAIS, Fernando. (coord.); ALENCASTRO, Luiz Felipe de (org.). História da vida privada no Brasil: Império. São Paulo: Companhia das Letras, 1997.

ALMEIDA, Alfredo Wagner Berno de. (orgs.) Caderno de debates Nova Cartografia Social: Territórios quilombolas e conflitos. Manaus: Projeto Nova Cartografia Social da Amazônia/UEA Edições, 2010.

BASTOS, Carlos Augusto. Nas rotas do Grão-Pará e Loreto: Comércio e fugas nas "Amazônias" peruana e brasileira (c. 1840- c. 1870). Anais Eletrônicos do VIII Encontro Internacional da ANPLHAC. Vitória, 2008.

BASTOS, Carlos Augusto. Tabatinga, 28 de maio de 1844: um motim na Fronteira Brasil-Peru. Usos do Passado. Anais do XIV Encontro Regional de História. Rio de Janeiro: ANPUH, 2006. BEZERRA NETO, José Maia. Historias Urbanas de Liberdade: Escravos em fuga na cidade de Belém, 1860-1888. Afro-Ásia, 28 (2002).

BEZERRA NETO, José Maia. Ousados e insubordinados: protesto e fugas de escravos na Província do Grão Pará, 1840/1860. Topói, Rio de Janeiro, 2001.

CALDEIRA, Newman. À margem da diplomacia: fugas internacionais de escravos do Brasil em direção à Bolívia (1822-1867). Outros tempos, vol. 6, n. 8, dezembro de 2009.

CALDEIRA, Newman. Fronteira Negra: as fugas internacionais de escravos do império do Brasil para a república da Bolívia (1825-1867). Ibero-América Global, vol. 2, n. 1, fevereiro de 2009.

CHALHOUB, Sidney. Medo Branco de Almas Negras: escravos, libertos e republicanos na cidade do Rio de Janeiro. Revista Brasileira de História. São Paulo, v.8, n.16.

COSTA, Emília Viotti da. Coroas de Glória, Lágrimas de Sangue: a rebelião de Demerara em 1823. São Paulo: Companhia das Letras, 1998.

FARIAS, Juliana B.; GOMES, Flávio dos S.; SOARES, Carlos Eugênio Líbano. No labirinto das nações: africanos e identidades no Rio de Janeiro, século XIX. Rio de Janeiro: Arquivo Nacional, 2005.

FUNES, Eurípedes A. "Nasci nas matas, nunca tive senhor": História e Memória dos mocambos no baixo Amazonas. In: REIS, João José \& GOMES, Flávio dos Santos (orgs.). Liberdade por um fio: história dos quilombos no Brasil. São Paulo: Companhia das Letras, 1996.

FUNES, Eurípedes A. Mocambos: natureza, cultura e memória. História Unisinos, n. 13, v. 21, maio/agosto 2009.

Revista Eletrônica da ANPHLAC, ISSN 1679-1061, n. 16, p. 26 - 56, Jan./Jul. 2014. http://revista.anphlac.org.br 
GENOVESE, Eugene. Da rebelião à revolução: as revoltas de escravos nas Américas. São Paulo: Global, 1983.

GOMES, Flavio dos Santos. Em torno dos bumerangues: outras histórias de mocambos na Amazônia Colonial. Revista da USP, São Paulo, n.28.

GOMES, Flávio. "No labirinto de rios, furos e igarapés": camponeses negros, memórias e pósemancipação na Amazônia, c. XIX e XX. História Unisinos, v. 10, n.3, set/dez 2006.

GOMES, Flavio. Etnicidade e fronteiras cruzadas nas Guianas. Estudos Afro-americanos Virtual, $\mathrm{n}^{\circ}$ 2, 2004.

GOMES, Flávio. Histórias de Quilombolas: Mocambos e Comunidades de fugitivos no Rio de Janeiro, século XIX. São Paulo: Companhia das Letras, 2006.

GREGÓRIO, Vitor Marcos. O progresso a vapor: navegação e desenvolvimento na Amazônia do século XIX. Nova Economia. Belo Horizonte, n. 19 (1), janeiro-abril de 2009.

HARRIS, Mark. Rebellion on the Amazon. The Cabanagem, Race, and Popular Culture in the North of Brazil, 1798-1840. Cambridge University Press, 2010.

LINEBAUGH, Peter. Todas as montanhas atlânticas estremeceram. Revista Brasileira de Historia, São Paulo, n.3/6, set. 1983.

MACHADO, Maria Helena P.T. Em torno da autonomia escrava: uma nova direção para a Historia Social da Escravidão. Revista Brasileira de História. São Paulo - SP. V.8, n.16, mar.88/ago.88.

MARCONDES, Renato Leite. Desigualdades regionais brasileiras: comércio marítimo e posse de cativos na década de 1870. Ribeirão Preto: Departamento de Economia da Faculdade de Economia, Administração e Contabilidade de Ribeirão Preto da Universidade de São Paulo, 2005.

MARCOY, Paul. Viagem pelo rio Amazonas. Manaus: Editora da Universidade Federal do Amazonas, 2006.

OLIVEIRA, Jane Souto de. "Brasil mostra a tua cara": imagens da população brasileira nos censos demográficos de 1872 a 2000. Rio de Janeiro: Ministério do Planejamento, Orçamento e Gestão; Instituto Brasileiro de Geografia e Estatística; Escola Nacional de Ciências Estatísticas, 2003.

PARRON, Tâmis. A política da escravidão no Império do Brasil, 1826-1865. Rio de Janeiro: Civilização Brasileira, 2011.

REGINALDO, Lucilene. Os rosários dos Angolas: irmandades negras, experiências escravas e identidades africanas na Bahia setecentista. Tese (Doutorado em História), Universidade Estadual de Campinas, Instituto de Filosofia e Ciências Humanas. Campinas, SP, 2005.

RICCI, Magda. Fronteiras da nação e da revolução: identidades locais e a experiência de ser brasileiro na Amazônia (1820-1840). In: Boletin Americanista, Año LVIII, n 58, Barcelona, 2008.

Revista Eletrônica da ANPHLAC, ISSN 1679-1061, n. 16, p. 26 - 56, Jan./Jul. 2014. http://revista.anphlac.org.br 
RUSSEL-WOOD, A. J. R. Escravos e libertos no Brasil Colonial. Rio de Janeiro: Civilização Brasileira, 2005.

SAMPAIO, Patrícia Melo. Escravidão e Liberdade na Amazônia: notas de pesquisa sobre o mundo do trabalho indígena e africano. $3^{\circ}$ Encontro Escravidão e Liberdade no Brasil Meridional Anais [do] II Encontro Escravidão e Liberdade no Brasil Meridional [recurso eletrônico] / 2005.

SANTOS, Ynaê Lopes. Além da Senzala: arranjos escravos de moradia no Rio de Janeiro (1808-1850). Dissertação (Mestrado em História Social), Universidade de São Paulo, 2006.

SOARES, Luiz Carlos Os escravos de ganho no Rio de Janeiro do século XIX. Revista Brasileira de Historia. São Paulo, v.8, n.16, mar.88/ago.88.

THOMPSON, Edward. Costumes em Comum: estudos sobre a cultura popular tradicional. São Paulo: Companhia das Letras, 1998.

THOMPSON, Edward. Senhores e Caçadores: a origem da lei negra. Rio de janeiro: Paz e Terra, 1987.

Revista Eletrônica da ANPHLAC, ISSN 1679-1061, n. 16, p. 26 - 56, Jan./Jul. 2014. http://revista.anphlac.org.br 